JURNAL MAKSIPRENEUR, Vol. VII, No. 1, Desember 2017, hal. 48-58

\title{
PERAN GURU DALAM MENUMBUHKAN INTENSI BERWIRAUSAHA PADA SISWA TUNA RUNGU DI SMPLB KARYA MULIA V SURABAYA
}

\author{
Bambang Purnomo \\ Fakultas Keguruan dan Ilmu Pendidikan, Universitas Dr Soetomo, Surabaya \\ Bambang Raditya Purnomo \\ Fakultas Ekonomi dan Bisnis, Universitas Dr Soetomo, Surabaya
}

Korespondensi penulis: bambang.purnomo@unitomo.ac.id

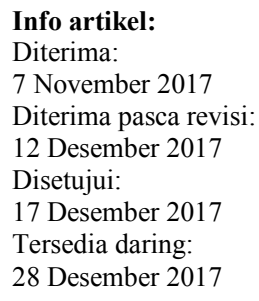

Abstract: This research is motivated by the lack of entrepreneurial intention of deaf students in SMPLB-B (Junior High-School for Disabled Children Type B) Karya Mulia V Surabaya, Indonesia in which so many alumni became laborers or even unemployed. Entrepreneurship intention is one of predisposition factors that determine a person's entrepreneurial behavior. One of which various aspect determines how much a person's intention to perform a behavior is the social environment in a student's life, especially teachers. This research also shows that the intention of entrepreneurship can be nurtured since an earlier age through education. As the student's main educator, teachers play an important role in the process. This article discusses how the role of teachers through parenting is done to foster entrepreneurship intention of the students by using theories of planned behavior.

Keywords: entrepreneurship, entrepreneurship intention, teacher, deaf students.

\section{PENDAHULUAN}

Indonesia adalah salah satu di antara sekian banyak negara berkembang yang memiliki permasalahan terkait kemiskinan dan pengangguran. Mulai dari masyarakat yang berpendidikan rendah hingga yang berpendidikan tinggi mengalami kesulitan dalam mencari pekerjaan. Hal ini terjadi karena sejumlah besar tenaga kerja memaksa ingin memasuki dunia kerja yang tidak sebanding dengan jumlah lapangan pekerjaan yang tersedia. Kesenjangan antara penawaran dan permintaan tenaga kerja tersebut menimbulkan dampak kemiskinan.

Salah satu faktor yang menyebabkan tingginya angka pengangguran di Indonesia adalah persepsi bahwa lebih mudah untuk menemukan pekerjaan di sektor formal sebagai karyawan atau pegawai. Hal ini yang menyebabkan banyak orang yang tidak ingin mencoba untuk menciptakan lapangan kerja sendiri di sektor usaha mikro. Ini akan mempengaruhi pertumbuhan ekonomi di Indonesia, sehingga sangat perlu untuk mencari solusi mengatasi pengangguran. Salah satu solusi agar seseorang dapat memiliki kemampuan ekonomi untuk menghidupi kehidupannya tanpa menggantungkan dirinya menjadi pegawai atau karyawan 
adalah memberikan pendidikan dan pembinaan kewirausahaan agar ia bisa menjadi pengusaha mikro. Hasilnya adalah tersedianya lapangan pekerjaan bagi orang lain. Untuk menjadi seorang pengusaha, yang diperlukan adalah bekal ketrampilan berwirausaha yang cukup.

Menurut data Badan Pusat Statistik (BPS) pada bulan Agustus 2010, jumlah angkatan kerja mencapai 116.500 .000 atau meningkat sekitar 530.000 orang dibandingkan bulan Februari 2010 dan mencapai 2,7 juta orang apabila dibandingkan dengan Agustus 2009. Warga yang bekerja pada Agustus 2010 meningkat 800 ribu orang dibandingkan bulan Februari 2010, dan mengalami kenaikan 3,3 juta orang dibandingkan Agustus 2010. Jumlah pengangguran pada Agustus 2010 mengalami penurunan sekitar 270.000 orang, apabila dibandingkan dengan bulan Februari 2010, dan mengalami penenurunan menjadi 640.000 orang, apabila dibandingkan dengan bulan Agustus, 2009 (BPS, 2012).

Tabel 1. Populasi Berdasarkan Bentuk Aktivitas Utama, Tahun 2008-2010 (dalam juta orang)

\begin{tabular}{lrrrrr}
\hline Bentuk Aktivitas Utama & $\mathbf{2 0 0 8}$ & \multicolumn{2}{c}{$\mathbf{2 0 0 9}$} & \multicolumn{2}{c}{$\mathbf{2 0 1 0}$} \\
\cline { 2 - 6 } & Agustus & Februari & Agustus & Februari & Agustus \\
\hline Populasi 15+ & 166,64 & 168,26 & 169,33 & 171,02 & 172,07 \\
Tenaga Kerja & 111,95 & 113,74 & 113,83 & 116,00 & 116,53 \\
Bekerja & 102,55 & 104,49 & 104,87 & 107,41 & 108,21 \\
Tidak Bekerja & 9,39 & 9,26 & 8,96 & 8,59 & 8,32 \\
\hline Sumber: BPS (2012). & & & &
\end{tabular}

Pada bulan Agustus 2010, sekitar 35,8 juta orang (33,06\%) bekerja di kegiatan formal dan 72,4 juta orang $(66,94 \%)$ bekerja di kegiatan informal. Dari 108,2 juta orang yang bekerja pada bulan Agustus 2010, pekerjaan berstatus sebagai buruh/karyawan sebesar 32,5 juta orang $(30,05 \%)$, bekerja sendiri dibantu oleh buruh tidak tetap sebesar 21,7 juta orang (20,04\%), dan bekerja sendiri 21 juta orang $(19,44 \%)$, sedangkan yang terkecil adalah dipekerjakan dengan dibantu oleh buruh tetap 3,3 juta orang (3,01\%). Pada tahun sebelumnya (Agustus 2009Agustus 2010), ada penambahan pekerja dengan status buruh/karyawan dari 3,4 juta orang, dan keluarga pekerja dengan jumlah 570.000 orang. Sementara status pekerja di sektor pertanian mengalami penurunan sebesar 64.000 orang (BPS, 2012).

Dari data tersebut di atas, tingkat kewirausahaan di Indonesia masih sangat rendah apabila dibandingkan dengan negara-negara lain. Amerika Serikat memiliki sekitar 11\%, Singapura 7\%, sedangkan di Indonesia hanya memiliki 0,24\% dari sekitar 237,6 juta orang di Indonesia yang memiliki kompetensi kewirausahaan. Kondisi ini juga mempengaruhi tingkat pengangguran. tenaga kerja cenderung ingin menjadi seorang pekerja, atau menjadi birokrat di kantor-kantor pemerintah, dan bukan pencipta lapangan kerja baru (Dipta, 2015). Untuk mencapai tingkat kemakmuran bukanlah tugas yang mudah. Banyak perubahan yang diperlukan, usaha dan kerja keras yang fokus dan sistematis oleh pemerintah dan keluarga, terutama untuk mengubah individu dari kondisi sekarang untuk menjadi pengusaha yang dibutuhkan. Menjadi seorang pengusaha seharusnya bukan menjadi profesi alternatif, tetapi sebagai pilihan strategis yang harus dilakukan dengan tekad yang kuat. Dalam kondisi saat ini, kunci kemakmuran adalah 
kewirausahaan. Kewirausahaan merupakan profesi yang sangat menjanjikan dalam mempromosikan kualitas hidup yang baik.

Untuk menumbuhkan intensi berwirausaha, maka dibutuhkan beberapa usaha yang menunjang tumbuhnya intensi berwirausaha pada siswa tersebut. Salah satu hal yang bisa menunjang tumbuhnya intensi berwirausaha adalah pendidikan dimana pendidikan kewirausahaan merupakan pendidikan yang mengajarkan seseorang agar mau dan mampu menciptakan kegiatan usahanya sendiri (Suherman, 2008). Beberapa studi telah menunjukkan bahwa intensi berwirausaha adalah konstrak kunci yang menentukan perilaku kewirausahaan (Andika \& Madjid, 2012). Individu yang memiliki niat yang kuat untuk memulai usaha akan memiliki kecenderungan yang besar untuk membuka usaha sendiri. Menurut Krueger dkk (2000), keterlibatan dalam aktivitas kewirausahaan tidak terjadi dengan sendirinya, melainkan disengaja oleh orang yang bersangkutan. Ini berarti bahwa untuk memulai bisnis, seseorang harus memiliki niat untuk memulai usaha. Jadi, intensi berwirausaha dapat dikatakan menjadi prediktor kuat untuk menentukan apakah seseorang akan memutuskan untuk berwiraswasta atau tidak.

Obschonka dkk. (2010) menemukan bahwa kewirausahaan dapat dikembangkan melalui pendidikan dan dapat dimulai pada usia dini. Lingkungan sosial dan orang-orang di sekitar individu yang terlibat dalam kegiatan kewirausahaan, seperti keluarga atau teman, dapat mempengaruhi sikap seseorang terhadap kewirausahaan. Sebaliknya, individu yang tidak tumbuh di lingkungan kewirausahaan akan cenderung menjadi karyawan di masa depannya (Mueller, 2008). Dari sudut pandang tersebut, artikel ini mencoba untuk menjelaskan bagaimana guru sebagai bagian dari lingkungan pendidikan siswa dapat mempengaruhi perkembangan intensi berwirausaha bagi siswa-siswi mereka.

\section{TINJAUAN TEORI}

\section{Tuna Rungu}

Penyandang tuna rungu adalah individu yang kehilangan seluruh atau sebagian daya pendengarannya, sehingga tidak atau kurang mampu berkomunikasi secara verbal dan walaupun telah diberikan pertolongan dengan alat bantu dengar masih tetap memerlukan pelayanan pendidikan khusus. Individu penyandang tuna rungu memiliki ciri-ciri sebagai berikut (Direktorat Pendidikan Luar Biasa Departemen Pendidikan Nasional, 2004):

a. Secara nyata tidak mampu mendengar.

b. Terlambat perkembangan bahasanya.

c. Sering menggunakan isyarat dalam berkomunikasi.

d. Kurang/tidak tanggap bila diajak bicara.

e. Ucapan kata tidak jelas.

f. Kualitas suara aneh/monoton.

g. Sering memiringkan kepala dalam usaha untuk mendengar.

h. Banyak perhatian terhadap getaran.

i. Keluar cairan "nanah" dari kedua telinga.

Seseorang dikatakan sebagai penyandang tuna rungu, apabila memenuhi minimal enam di antara ciri-ciri tersebut. Secara medis, tuna rungu berarti kekurangan atau kehilangan kemampuan mendengar yang disebabkan oleh keru- 
sakan atau tidak berfungsinya sebagian atau seluruh alat pendengarannya. Secara pedagogis, tuna rungu berarti kekurangan atau kehilangan alat pendengaran yang mengakibatkan hambatan dalam perkembangan bahasa, sehingga ia memerlukan bimbingan dan pendidikan khusus (Sastrawinata, 1976). Dari kedua definisi di atas, maka yang dimaksud dengan tuna rungu dalam tulisan ini adalah individu yang mengalami kekurangan atau kehilangan kemampuan mendengar yang disebabkan oleh kerusakan atau tidak berfungsinya sebagian atau seluruh alat pendengarannya, sehingga tidak atau kurang mampu berkomunikasi secara verbal, meskipun ia telah diberikan pertolongan dengan alat bantu dengar tetapi masih tetap memerlukan pelayanan pendidikan khusus.

\section{Intensi Berwirausaha}

Intensi diasumsikan sebagai faktor motivasi yang mempengaruhi perilaku, yang menunjukkan seberapa keras seseorang akan mencoba untuk mewujudkan suatu perilaku (Ajzen, 1991). Seiring dengan definisi tersebut, intensi berwirausaha didefinisikan sebagai keadaan kesadaran yang mengarahkan perhatian, pengalaman, dan perilaku masyarakat terhadap perilaku kewirausahaan (Bird, 1988). Intensi berwirausaha telah terbukti menjadi prediktor terkuat dari perilaku kewirausahaan. Dalam bentuk yang paling sederhana, intensi dapat memprediksi perilaku, dan intensi itu sendiri diprediksi oleh sikap-sikap tertentu (Khuong \& An, 2016). Studi yang dilakukan oleh Kristiansen dan Indarti (2004) menunjukkan bahwa intensi berwirausaha dipengaruhi oleh jenis kelamin, self-efficacy, latar belakang pendidikan, dan kesiapan instrumental (akses ke modal, ketersediaan informasi, dan jaringan sosial). Teori Planned-Behavior yang dikembangkan oleh Fishbein dan Ajzen (2010) sering digunakan untuk menjelaskan bagaimana peran intensi dalam pembentukan perilaku.

Gambar 1 berikut menunjukkan bahwa intensi adalah prediktor utama perilaku dengan mempertimbangkan ketrampilan/kemampuan dan faktor lingkungan. Ada tiga hal yang mempengaruhi intensi, yaitu sikap terhadap perilaku, persepsi terhadap norma, dan kontrol perilaku. Seseorang akan melakukan sesuatu jika ia memiliki sikap positif terhadap perilaku tersebut dan mereka merasa norma di sekitar mereka dan menuntut mereka untuk melakukannya. Selain itu, penilaian kemampuan sendiri untuk melakukan perilaku seperti itu juga penting. Namun, ketiga aspek tersebut memiliki tingkat yang berbeda berdasarkan pada keyakinan, norma, dan kontrol tertentu. Hal ini menjelaskan mengapa orang dengan sikap, norma, dan persepsi kontrol yang sama dapat berperilaku berbeda, tergantung faktor mana yang memiliki pengaruh lebih besar. Hal ini pada tingkat analisis lebih lanjut dipengaruhi oleh faktor individu, sosial, dan informasi tentang perilaku. Pertanyaannya adalah bagaimana guru dapat mempengaruhi tiga aspek intensi tersebut pada siswa-siswinya untuk mendorong intensi berwirausaha? 


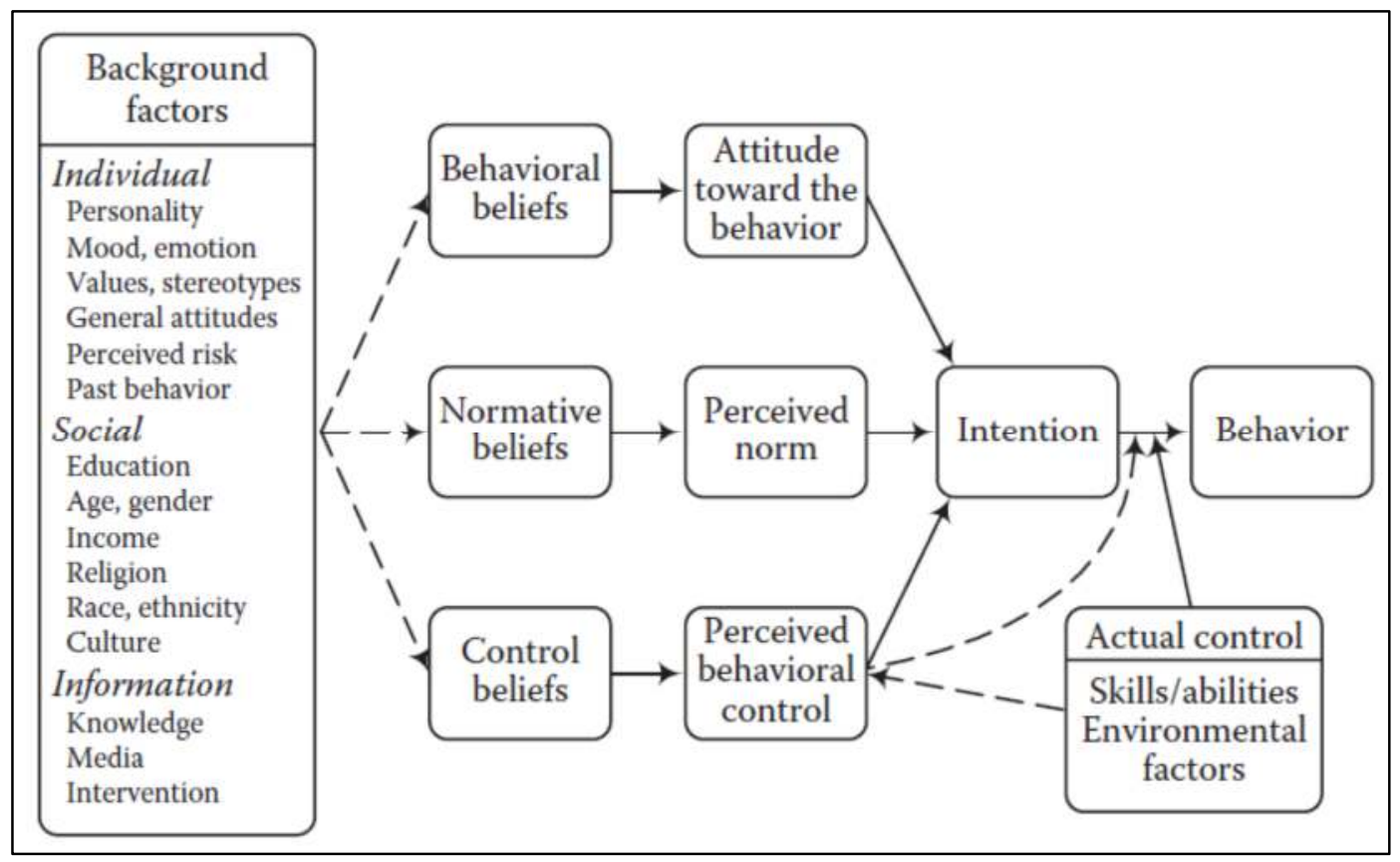

Sumber: Fishbein \& Ajzen (1975).

Gambar 1. Theory of Planned Behavior

\section{METODE PENELITIAN}

Penelitian ini merupakan penelitian kualitatif dengan pendekatan fenomenologi, yaitu peneliti mencoba menjelaskan atau mengungkapkan makna konsep atau fenomena pengalaman yang didasari oleh kesadaran yang terjadi pada beberapa individu. Dalam penelitian ini, peneliti mengumpulkan, merangkum, dan menginterpretasikan data yang diperoleh, kemudian data tersebut diolah kembali, sehingga diperoleh gambaran yang jelas, terarah, dan menyeluruh dari masalah yang menjadi obyek penelitian ini.

Subyek sebagai informan kunci dalam penelitian ini adalah pejabat struktural dan staf pengajar di SMPLB Tipe B Karya Mulia V Surabaya. Selain itu, peneliti juga menetapkan beberapa orang siswa sebagai informan biasa. Pengumpulan data dalam penelitian ini dilakukan dengan menggunakan teknik wawancara, studi kepustakaan, dan dokumentasi. Wawancara dilakukan kepada kepala sekolah dan guru-guru sebagai informan utama dan siswa sebagai informan biasa. Analisis data pada penelitian ini dilakukan dengan pendekatan diskriptif kualitatif.

\section{SMPLB Tipe B Karya Mulia V Surabaya}

Sekolah Luar Biasa tuna rungu Karya Mulia Surabaya berdiri sejak tahun 1954 di Jalan Bengawan Surabaya bernama SLB Bisu Tuli Karya Mulia. Pada perkembangan berikutnya yaitu tahun 1977, sekolah tersebut menempati gedung sendiri di Jalan Achmad Yani 6-8 Surabaya yang diresmikan oleh Gubernur Jawa Timur saat itu, Soenandar Prijosoedarmo pada tanggal 14 Agustus 1977 dengan nama SLB Tunarungu Karya Mulia. Sebelumnya, sekolah ini merupakan pindahan dari gedung kompleks di Jalan Darmokali 69 Surabaya. Dengan dimilikinya gedung sekolah di Jalan Achmad Yani 6-8 Surabaya, maka sekolah luar biasa 
mulai dikenal masyarakat akan pentingnya pendidikan bagi anak penyandang tuna rungu agar mereka nantinya dapat hidup secara mandiri. Dengan kesadaran ini, masyarakat mulai menyekolahkan putra-putrinya yang tuna rungu ke SLB-B Karya Mulia Surabaya agar mendapat layanan pendidikan sebagaimana anak-anak pada umumnya.

Sekolah Lanjutan Tingkat Pertama Luar Biasa (SLTPLB) tuna rungu Karya Mulia Surabaya dibuka dan diresmikan pada tanggal 20 Juli 1994. Selanjutnya, pada tahun 2004 nama SLTPLB berganti menjadi SMPLB. Sekolah ini memliliki program ketrampilan/vokasional: (1) menjahit, (2) potong rambut/kecantikan, (3) ketik dan komputer, (4) cetak/sablon, (5) akupresur/pijat refleksi, dan (6) tata boga.

\section{ANALISIS DAN PEMBAHASAN}

\section{Program Kewirausahaan di Sekolah}

Berdasarkan wawancara dengan Kepala Sekolah SMPLB Tipe B Karya Mulia V Surabaya, yaitu Bapak drs. H. Sumarman, M.Pd., pembinaan kewirausahaan di sekolah diberikan sebatas mengajarkan ketrampilan teknis pada siswa melalui pelajaran ketrampilan dan vokasional. Belum ada program khusus untuk membina jiwa kewirausahaan pada siswa. Subyek mengungkapkan bahwa pengembangan sikap dan ketrampilan tersebut terintegrasi dalam kegiatan siswa sehari-hari. Siswa SMPLB-B Karya Mulia telah dibekali ketrampilan teknis yang dapat mereka jadikan bekal untuk berwirausaha. Ketrampilan tersebut diajarkan dalam mata pelajaran ketrampilan dan vokasional yang terdiri atas enam bentuk ketrampilan, yaitu menjahit, memotong rambut/kecantikan, mengetik dan komputer, mencetak/sablon, akupresur/pijat refleksi, dan tata boga. Ketrampilan tersebut diberikan di tiap kelas dan berlaku untuk satu semester, serta dilaksanakan bergantian, sehingga seluruh siswa mengikuti ketrampilan tersebut (sistem rolling).

Ketrampilan menjahit, memotong rambut, mengetik, tata boga, dan mencetak/sablon diberikan di kelas 1. Di kelas 2, siswa mendapatkan ketrampilan menjahit, percetakan, tata boga, dan komputer. Kelas 3 mendapatkan ketrampilan menjahit, tata boga, komputer, rias wajah/kecantikan, dan pijat refleksi. Dalam pelajaran ketrampilan potong rambut dan tata rias, siswa diajari materi dasar-dasar memotong rambut, mencuci rambut, mengenal berbagai alat perawatan rambut, cara membagi wilayah rambut, dan menyanggul di kelas 1 . Di kelas 3, siswa diajari cara merias wajah untuk berbagai acara dan cara melakukan creambath. Mereka tidak hanya diberi materi, tetapi juga dilatih melalui praktik, karena dengan materi saja mereka akan sulit untuk mendapatkan pemahaman.

Untuk ketrampilan menjahit, siswa diajarkan teori dasar penjahitan dengan menggunakan media alat dan gambar. Mereka juga diajar melalui praktik menjahit dan dipacu minat menjahitnya dengan berkompetisi antara satu siswa dengan siswa yang lain. Dalam pelajaran tata boga, siswa diajar cara membuat kue, menghias roti, dan memasak berbagai hidangan sederhana. Siswa juga dibekali dengan ketrampilan percetakan dan komputer. Dalam ketrampilan ini, mereka diajarkan cara menyablon di berbagai media, seperti kaos, tas, gelas, dan sebagainya. Mereka juga diajarkan cara membuat kartu nama, undangan, amplop, dan sebagainya. 


\section{Sikap terhadap Kewirausahaan}

Sikap adalah evaluasi dari suatu obyek, baik di tingkat umum maupun khusus (Robinson dkk, 1991). Untuk mengukur sikap terhadap domain tertentu secara akurat, maka perlu dijelaskan dimensi sikap secara khusus. Ada dua kelompok teori tentang sikap, yaitu sikap sebagai konstrak unidimensional (Fishbein \& Ajzen, 1975) dan sikap sebagai konstrak multidimensional (Rosenberg \& Hovland, 1960). Pendekatan unidimensional menyatakan bahwa sikap ditunjukkan dalam bentuk reaksi afektif, sedangkan pendekatan multidimensional atau pendekatan tripartit mengatakan bahwa sikap adalah kombinasi dari tiga bentuk respon, yaitu kognitif, afektif, dan konatif. Komponen kognitif terdiri atas keyakinan dan pikiran individu terhadap obyek sikap. Komponen afektif terdiri atas perasaan positif atau negatif terhadap objek sikap. Komponen konatif atau perilaku terdiri atas intensi berperilaku dan kecenderungan untuk berperilaku dengan cara tertentu terhadap obyek tersebut.

Penelitian ini menunjukkan bahwa sikap terhadap kewirausahaan adalah efek langsung dan tidak langsung yang signifikan dari pengalaman adanya bisnis keluarga, melalui variabel sikap terhadap kepemilikan bisnis, dukungan pihak sekolah, dan entrepreneurial self-eficacy (Carr \& Sequeira, 2007). Ini berarti guru yang memiliki bisnis sendiri, atau keterlibatan siswa dalam suatu kegiatan kewirausahaan, dan adanya dukungan dari pihak sekolah untuk para siswa tersebut untuk terlibat dalam aktivitas kewirausaha-siswaan akan meningkatkan probabilitas siswa dalam membentuk sikap positif terhadap kewirausahaan. Jika guru tidak memiliki bisnis sendiri, maka dukungan guru juga dapat membantu, seperti melibatkan siswa-siswi dalam kegiatan ekstra yang berkaitan dengan kewirausahaan, atau memfasilitasi siswa untuk belajar kewirausahaan. Membawa siswa ke tempat-tempat tertentu yang menunjukkan kegiatan kewirausahaan atau memperkenalkan siswa kepada orang-orang yang memiliki bisnis mereka sendiri juga merupakan upaya yang dapat guru lakukan dalam membentuk sikap positif terhadap kewirausahaan.

\section{Mentransmisikan Nilai dan Norma Kewirausahaan pada Siswa}

Ada berbagai jenis norma. Salah satu jenis norma mengacu pada sikap atau apa yang menurut individu benar berdasarkan moral atau keyakinan (injunctive norm). Tipe kedua dari norma berkaitan dengan perilaku, yaitu apa yang benarbenar dilakukan individu (descriptive norm). Para peneliti menunjukkan bahwa perilaku lebih mungkin diprediksi dengan norma-norma injunctive daripada norma diskriptif (Borsari \& Carey, 2003). Setiap individu memiliki teman, menjadi anggota dari suatu kelompok, tinggal di asrama di kampus-kampus, dan merupakan bagian dari komunitas yang lebih besar. Masing-masing kelompok yang tumpang tindih ini memiliki norma-norma yang mungkin sama atau berbeda, dan beberapa atau semua norma-norma ini dapat memberikan pengaruh pada perilaku individu. Di antara target norma-norma, kesalahan persepsi yang meningkat dapat seiring dengan meningkatnya jarak sosial, dan kelompok-kelompok sosial yang "dekat" lebih berpengaruh dalam membentuk perilaku (Berkowitz, 2004). Dapat disimpulkan bahwa kedekatan antara guru dan siswa dapat membantu membentuk norma sosial yang diyakini oleh siswa.

Lebih khusus, Grusec dan Goodnow (1994) menyatakan bahwa ada dua langkah yang terjadi dalam proses penyamaan nilai antara guru dan siswa. Pada 
langkah pertama, siswa harus benar-benar memahami nilai-nilai apa yang ingin ditanamkan oleh guru. Kedua, siswa harus menerima nilai-nilai tersebut sebagai nilai-nilai mereka sendiri. Pada langkah pertama siswa dapat memahami secara akurat, jika tidak maka akan terjadi kesalahan persepsi tentang nilai yang ditanamkan guru. Pada tahap kedua, siswa mungkin menerima atau menolak nilainilai yang ditanamkan oleh guru. Dengan kata lain, agar memungkinkan terjadinya transmisi, nilai yang ditanamkan guru harus kongruen dengan nilai siswa. Berkaitan dengan kewirausahaan, tidak dapat dipungkiri bahwa jika guru ingin siswa-siswi mereka memiliki intensi berwirausaha yang kuat, maka guru juga perlu untuk mengadopsi nilai-nilai kewirausahaan dalam diri mereka dan kehidupan mereka. Kecharananta dan Baker (1999) menunjukkan nilai-nilai ini termasuk kemerdekaan, kreatifitas, kerjasama, dan kepercayaan. Sementara, Arkush (1984) menyimpulkan bahwa nilai yang mendasari semangat kewirausahaan adalah kerja keras.

Akurasi dalam mempersepsikan nilai guru lebih besar kemungkinan terjadinya jika ada kesepakatan nilai antara guru dan siswa di dalam sekolah (Knafo \& Schwartz, 2009). Kesepakatan guru dan siswa dapat memberikan pesan nilai yang lebih konsisten dan tidak membingungkan dan lebih mudah untuk dipahami secara akurat. Dikarenakan siswa cenderung melihat guru mereka sebagai model, maka mereka mungkin akan menangkap lebih banyak pesan nilai dari guru tersebut dan memahaminya dengan cukup akurat, meskipun ada ketidaksepakatan dengan gurunya.

Dari proses transmisi di atas, komunikasi antara guru dan siswa menjadi sangat penting. Komunikasi yang efektif harus terjadi antara guru dan siswa. Hal ini bertujuan untuk menyamakan nilai-nilai yang akan ditransmisikan antara guru dan siswa untuk menghindari kesalahan persepsi. Komunikasi antara guru dan siswa dimaksudkan untuk menyampaikan dan menanamkan nilai-nilai tersebut pada para siswa. Hill dan Taylor (2004) menemukan bahwa komunikasi akan efektif dan tepat, jika guru juga terlibat dalam kegiatan yang dilakukan siswa. Dengan kata lain, guru tidak hanya menyarankan tetapi juga memberikan contoh dan meluangkan waktu untuk memahami kebutuhan siswa, sehingga siswa mau mendengarkan gurunya. Ini akan menjadi awal dari penerimaan nilai yang ditanamkan oleh guru.

\section{Peningkatan Entrepreneurial Self-Efficacy (ESE)}

Bandura (dalam Schunk, 1990) mendefinisikan self-efficacy sebagai pertimbangan kemampuan seseorang untuk mengatur dan melaksanakan tindakan yang diperlukan untuk mencapai kinerja tertentu. Self-efficacy juga didefinisikan sebagai pendapat atau keyakinan yang dimiliki oleh seseorang tentang kemampuannya dalam melakukan suatu bentuk perilaku dan hal ini berhubungan dengan situasi yang dihadapi oleh orang tersebut, sehingga ia meletakkannya sebagai unsur kognitif pembelajaran sosial. Efikasi menentukan seberapa besar usaha yang akan dilakukan dan bagaimana orang bertahan hidup dalam menghadapi rintangan dan pengalaman yang menyakitkan. Semakin kuat persepsi individu terhadap self-efficacy, maka lebih besar usaha yang akan ia berikan. Ketika menghadapi kesulitan, orang yang memiliki keraguan besar tentang kemampuan mereka akan mengurangi usaha mereka atau menyerah sama sekali. Sementara, 
mereka yang memiliki rasa keberhasilan yang kuat akan menggunakan upaya yang lebih besar untuk mengatasi tantangan (Bandura, 1986).

Bandura (1997) mengusulkan dua cara yang berbeda untuk memperkuat efikasi siswa. Cara pertama dihasilkan melalui dukungan, dorongan, dan pemodelan positif. Misalnya, jika siswa-siswi yang diberi tugas menantang pada usia dini, ia didorong untuk melakukan tugas-tugas tersebut, dan diberikan pujian, maka ia akan memiliki self-efficacy yang lebih tinggi. Cara kedua berasal dari pengalaman melalui belajar untuk mengatasi kondisi-kondisi buruk yang dihadapi. Tabel 2 memberikan gambaran contoh hal-hal yang berpotensi mempengaruhi self-efficacy dalam berbagai tahap perkembangan siswa.

Tabel 2. Faktor yang Berpotensi Mempengaruhi Self-Efficacy Siswa

\begin{tabular}{|c|c|c|c|c|}
\hline & Pengalaman & $\begin{array}{l}\text { Vicarious } \\
\text { experiencel } \\
\text { modeling }\end{array}$ & $\begin{array}{l}\text { Persuasi } \\
\text { sosial/verbal }\end{array}$ & $\begin{array}{l}\text { Judgement } \\
\text { tentang } \\
\text { kondisi } \\
\text { psikologis }\end{array}$ \\
\hline $\begin{array}{l}\text { Masa bayi dan } \\
\text { ksiswa-ksiswa } \\
\text { (rumah, TK, } \\
\text { dan } \\
\text { prasekolah) }\end{array}$ & $\begin{array}{l}\text { Pemilihan } \\
\text { mainan dan } \\
\text { aktivitas }\end{array}$ & $\begin{array}{l}\text { Reference group : } \\
\text { Guru }\end{array}$ & $\begin{array}{l}\text {-Dongeng } \\
\text {-Acara TV Siswa } \\
\text {-Guru TK }\end{array}$ & $\begin{array}{l}\text { Latihan dan } \\
\text { aktivitas fisik }\end{array}$ \\
\hline $\begin{array}{l}\text { Remaja } \\
\text { (sekolah, } \\
\text { sekolah } \\
\text { menengah) }\end{array}$ & $\begin{array}{l}\text { Partisipasi } \\
\text { dalam olahraga } \\
\text { pada level yang } \\
\text { lebih tinggi. }\end{array}$ & $\begin{array}{l}\text { Reference groups } \\
\text { : guru, teman } \\
\text { sebaya }\end{array}$ & $\begin{array}{l}\text {-Media } \\
\text {-Guru } \\
\text {-Cara mengajarkan } \\
\text { dan menghargai } \\
\text { perilaku yang tepat }\end{array}$ & $\begin{array}{l}\text { Aktivitas dan } \\
\text { latihan fisik: } \\
\text { berpartisipasi } \\
\text { dalam } \\
\text { olahraga }\end{array}$ \\
\hline $\begin{array}{l}\text { Dewasa Muda } \\
\text { (Universitas) }\end{array}$ & $\begin{array}{l}\text { Partisipasi } \\
\text { dalam kegiatan } \\
\text { olahraga pada } \\
\text { level yang lebih } \\
\text { tinggi }\end{array}$ & $\begin{array}{l}\text { Reference group : } \\
\text { keluarga, sebaya, } \\
\text { wirausaha yang } \\
\text { sudah sukses }\end{array}$ & $\begin{array}{l}\text {-Guru } \\
\text {-Media } \\
\text {-Sebaya } \\
\text {-Pelatih dan mentor }\end{array}$ & $\begin{array}{l}\text {-Partisipasi } \\
\text { dalam } \\
\text { olahraga pada } \\
\text { level yang } \\
\text { lebih tinggi } \\
\text {-Mempersiapk } \\
\text { an dan } \\
\text { menghadiri } \\
\text { ujian }\end{array}$ \\
\hline
\end{tabular}

Sekolah merupakan lingkungan sosialisasi yang paling penting (Gecas, 1989). Pengkondisian pikiran sudah terjadi ketika guru memberikan dukungan, dorongan, dan harapan yang jelas kepada siswa-siswi mereka, sehingga mereka dapat merasa dirinya kompeten. Dengan demikian, guru yang memberikan pengaruh yang merangsang, menantang, dan menciptakan lingkungan yang responsif dan memberikan siswa-siswi mereka kebebasan untuk terlibat di dalamnya akan menghasilkan siswa-siswi yang lebih percaya diri. Siswa-siswi juga belajar untuk mengembangkan strategi coping melalui pemodelan dari guru mereka (Bandura, 1997).

\section{KESIMPULAN}

Dari pembahasan tersebut di atas, peran guru sangat penting dalam pengembangan intensi berwirausaha pada siswa-siswinya. Namun, tidak banyak 
guru yang menyadari hal ini dan lebih mengandalkan sistem pendidikan formal untuk melakukan tugas tersebut. Pada dasarnya, semua pihak bertanggung jawab atas pendidikan kewirausahaan, kerjasama di antara mereka sangat penting, karena pendidikan yang komprehensif akan membawa hasil yang lebih matang daripada usaha yang dilakukan secara sporadis dan parsial. Selanjutnya, perlu disadari bahwa artikel ini tidaklah mencukupi dalam membahas tentang pembentukan semangat dan kompetensi kewirausahaan pada siswa-siswi. Perlu penelitian lebih lanjut yang dapat memperhitungkan aspek-aspek lain, seperti kepribadian dan motivasi untuk berwirausaha.

\section{DAFTAR REFERENSI}

Ajzen, I. (1991). The Theory of Planned Behavior. Organizational Behavior and Human Decision Processes, 50(2), 179-211.

Andika, M., \& Madjid, I. (2012). Analisis Pengaruh Sikap, Norma Subyektif dan Efikasi Diri Terhadap Intensi Berwirausaha Pada mahasiswa Fakultas Ekonomi Universitas Syiah Kuala. In Eco-Entrepreneurship Seminar \& Call for Paper: Improving Performance by Improving Environment, 190-196.

Arkush, R. D. (1984). If Man Works Hard the Land Will Not Be Lazy: Entrepreneurial Values in North Chinese Peasant Proverbs. Modern China, 10(4), 461-479.

Badan Pusat Statistik. (2012). Keadaan Ketenagakerjaan Agustus 2012. Berita Resmi Statistik Badan Pusat Statistik, (74/11).

Bandura, A., Reese, L., \& Adams, N.E. (1986). Microanalysis of Action and Fear Arousal as a Function of Different Levels of Perceived Self Efficacy. Journal of Personality and Social Psychology, 43(1), 5-21.

Bandura, A. (1997). Self-efficacy The Exercise of Control. New York: W.H. Freeman and Company.

Berkowitz, A.D. (2004). The Social Norms Approach: Theory, Research, and Annotated Bibliography.

Bird, B. (1988). Implementing Entrepreneurial Ideas: The Case for Intention. Academy of Management Review, 13(3), 442-453.

Borsari, B. \& Carey, K.B. (2003). Descriptive and Injunctive Norms in College Drinking: A Meta-analytic Integration. Journal of Studies on Alcohol, 64, 331-341.

Carr, J.C. \& Sequeira, J.M. (2007). Prior Family Business Exposure as Intergenerational Influence and Entrepreneurial Intent: A Theory of Planned Behavior Approach. Journal of Business Research, 60(10), 1090-1098.

Dipta, I.W. (2005). Model Pengembangan Wirausaha. INFOKOP, 19(1).

Fishbein, M. \& Ajzen, I. (1975). Belief, Attitude, Intention, and Behavior: An Introduction to Theory and Research. MA: Addison-Wesley, Inc.

Fishbein, M. \& Ajzen, I. (2010). Predicting and Changing Behavior. New York: Psychology Press. 
Gecas, V. (1989). The Social Psychology of Self-efficacy. Annual Review of Sociology, 15, 291-316.

Grusec, J.E., \& Goodnow, J.J. (1994). Impact of Parental Discipline Methods on the Child's Internalization of Values: A Reconceptualization of Current Points of View. Developmental Psychology, 30, 4-19.

Hill, N.E. \& Taylor, L.C. (2004). Parental School Involvement and Children's Academic Achievement Pragmatics and Issues. Current Directions in Psychological Science, 13(4), 161-164.

Kecharananta, N. \& Baker, H.G. (1999). Capturing Entrepreneurial Values. Journal of Applied Social Psychology, 29(4), 820-833.

Khuong, M.N. \& An, N.H. (2016). The Factors Affecting Entrepreneurial Intention of the Students of Vietnam National University-A Mediation Analysis of Perception Toward Entrepreneurship. Journal of Economics, Business and Management, 4(2).

Knafo, A., \& Schwartz, S.H. (2009). Accounting for Parent-child Value Congruence: Theoretical considerations and empirical evidence.

Kristiansen, S., \& Indarti, N. (2004). Entrepreneurial Intention Among Indonesian and Norwegian Students. Journal of Enterprising Cuture, 12(01), 55-78.

Krueger, N.F., Reilly, M.D., \& Carsrud, A.L. (2000). Competing Models of Entrepreneurial Intentions. Journal of Business Venturing, 15(5), 411-432.

Mueller, S. (2008). Increasing Entrepreneurial Intention: Effective Entrepreneurship Course Characteristics. International Journal of Entrepreneurship and Small Business, 13(1), 55-74.

Obschonka, M., Silbereisen, R.K., \& Schmitt-Rodermund, E. (2010). Entrepreneurial Intention as Developmental Outcome. Journal of Vocational Behavior, 77(1), 63-72.

Robinson, P.B., Stimpson, D.V., Huefner, J.C., \& Hunt, H.K. (1991). An Attitude Approach to the Prediction of Entrepreneurship. Entrepreneurship Theory and Practice, 15(4), 13-31.

Rosenberg, M.J., \& Hovland, C.I. (1960). Cognitive, Affective, and Behavioral Components of Attitudes. Attitude Organization and Change: An Analysis of Consistency among Attitude Components, 3, 1-14.

Schunk, D.H. (1990). Introduction to the Section on Motivation and Efficacy. Journal of Educational Psychology, 82(1), 3-6. 